\title{
Automatic technique for titration of influenza virus haemagglutination inhibitors
}

\author{
A. COHEN \\ From the Department of Bacteriology, University College Hospital Medical School, London
}

SYNOPSIS An automatic method, utilizing the AutoAnalyzer, for titration of influenza virus haemagglutination inhibitors is described. The titres obtained compare favourably with those obtained by densitometric methods. So far, the technique has not proved superior to the densitometric methods in either speed of operation or in reproducibility but various developments are suggested to effect this.

The continuous-flow technique for the automation of chemical reactions which produce a direct or indirect colour reaction was introduced by Skeggs in 1957 and is now used routinely in many laboratories. The adaptation of the technique to virus and other haemagglutination reactions has now been made possible by the development of special devices capable of separating agglutinated from unagglutinated red cells (Sturgeon, Cedergren, and McQuiston, 1963; Grunmeier, Gray, and Ferrari, 1965; Morris, Jenkins, and Horswood, 1965). Its further modification for the performance of influenza virus haemagglutination-inhibition titrations is a development which should prove of benefit to those laboratories engaged in large-scale survey work or in research projects necessitating numerous such titrations for which some degree of precision is required. Currently, precise haemagglutinationinhibition titres can only be estimated by the photoelectric densitometer methods of titration, first introduced by Hirst and Pickels (1942). Because these methods are very laborious and time consuming, preliminary studies have been made to investigate the feasibility of using the continuousflow technique for titrating influenza virus haemagglutination inhibitors, and to define its characteristics.

\section{MATERIALS}

VIRUS An inhibitor-sensitive variant of the $\mathrm{A}_{2}$ /Singapore/1/57 strain was used throughout. Batches of virus were prepared, as required, by allantoic inoculation of 11-day-old embryonated hens' eggs; virus from the harvested allantoic fluids was purified by one cycle of red cell adsorption and elution, followed by chromatography on a calcium phosphate column (Taverne, Marshall, and Fulton, 1958).

Received for publication 21 April 1966.
SERA Two normal sera and one immune serum were used.

Normal horse Normal serum from a single horse was obtained commercially from Burroughs Wellcome and Company. This serum (Wellcome brand no. 2) is heated at $56^{\circ} \mathrm{C}$. for two hours before distribution.

Normal rabbit Normal serum from a single rabbit was obtained from naturally clotted whole blood. It was used uninactivated.

Rabbit immune serum Immune serum was prepared by the intravenous administration of 100 haemaglutination doses of purified $A_{2} /$ Singapore/1/57 virus. Serum was collected from naturally clotted whole blood 23 days after injection of virus and was used uninactivated.

ERYTHROCYTE SUSPENSIONS Fowl red cells were withdrawn by venepuncture into citrate-saline and used within four days of their collection. After separation from plasma they were washed three times in physiological saline, and $4 \%$ suspensions were made in borate-buffered saline, $p \mathrm{H} 7 \cdot 6$. Usually, suspensions were prepared by pooling cells obtained from two to four different fowls. Final adjustment of the concentration was effected by means of a photo-electric densitometer. Each day before use the cells were resuspended in fresh saline and filtered through several layers of gauze.

SALINE WASH Between each sample a saline wash is inserted automatically from the sampler module. For this purpose borate buffered saline, $p \mathrm{H} 7 \cdot 6$, to which was added the wetting agent Tween $20(0 \cdot 2 \mathrm{ml}$./litre), was used.

SODIUM HYDROXIDE Two per cent sodium hydroxide (Analar $\mathrm{NaOH})$ was used, to which Tween $20(0.2 \mathrm{ml}$./ litre), was added as wetting agent.

\section{TECHNIQUE OF THE TEST}

Apart from the special lucite decantation T-pieces, introduced by Smythe in 1963, for separating agglutinated 
from unagglutinated red cells, the apparatus for influenza virus haemagglutination-inhibition titrations consists of standard AutoAnalyzer modules, the same as those used for biochemical tests. It consists of an automatic sampler for sampling the test material and introducing the intersample saline wash, proportioning pumps which aspirate the reagents into the closed system of tubes and glass fittings in which agglutination takes place, a colorimeter for quantitating haemoglobin released from unagglutinated cells, and a pen recorder.

The first problem in adapting the system for haemagglutination-inhibition tests was to determine the best combination of standard AutoAnalyzer components which would provide results of maximum sensitivity combined with a minimum degree of contamination between samples. This depended on the rates at which the reagents were delivered, the time allowed for their interaction, the rate of sampling and the ratio of sample to saline wash. After some months of trial and error the system illustrated in Fig. 1 proved to be the one which gave optimal performance with a sampling rate of 20 per hour and a sample/wash ratio of $1: 3$.

Air is first introduced into the virus flow converting it into an air-segmented stream. Virus and inhibitor sample are then mixed in proportions of approximately $1: 1.5$ in three mixing coils, allowing a reaction time of six and three-quarter minutes. A $4 \%$ suspension of fowl red cells is then introduced at the rate of $0.096 \mathrm{ml}$. per minute and agglutination is allowed to develop in two mixing coils, giving a reaction time of four and a half minutes.

When agglutination has reached a maximum, sedimentation of agglutinates in the flowing suspension is allowed to take place in a two and a half turn settling 은 coil. Agglutinated cells are then withdrawn through the $\Rightarrow$ vertical limb of the decantation T-piece with the aid of a second proportioning pump which draws off a fixedo fraction of the total flow (Fig. 2). Any agglutinates which드 remain are allowed to sediment a second time in a $\overline{\bar{s}}$ one and a half turn settling coil and are withdrawn $\mathbb{\Phi}$ through a second decantation T-piece. Unagglutinated cells are now lysed by the addition of $2 \%$ sodiumes hydroxide, and, after thorough mixing, the residual $\overrightarrow{0}$ haemoglobin is measured as alkaline haematin at $420 \mathrm{~m} \mu$ in a colorimeter and the results recorded on a pen $\vec{\omega}$ recorder.

If haemagglutination by live influenza virus is allowed to develop at room temperature, virus elution with con-: sequent disaggregation of cells is easily visible in the mixing coils. Failure to achieve maximum agglutination $\sigma$ under these conditions makes it impossible to titrate inhibitor (Fig. 3). For this reason, all parts of the mani-o fold in which virus and erythrocytes interact must be maintained at a temperature of 0 to $4^{\circ} \mathrm{C}$. In the system described here these parts are immersed in crushed ice. Suspensions of cells and virus which are fed into the machine are likewise held in crushed ice and the former 3 is continuously mixed by a magnetic stirrer.

\section{RESULTS}

HAEMAGGLUTINATION-INHIBITION TITRATIONS The data analysed in this paper have been obtained from titrations of antibody in homologous immune rabbit

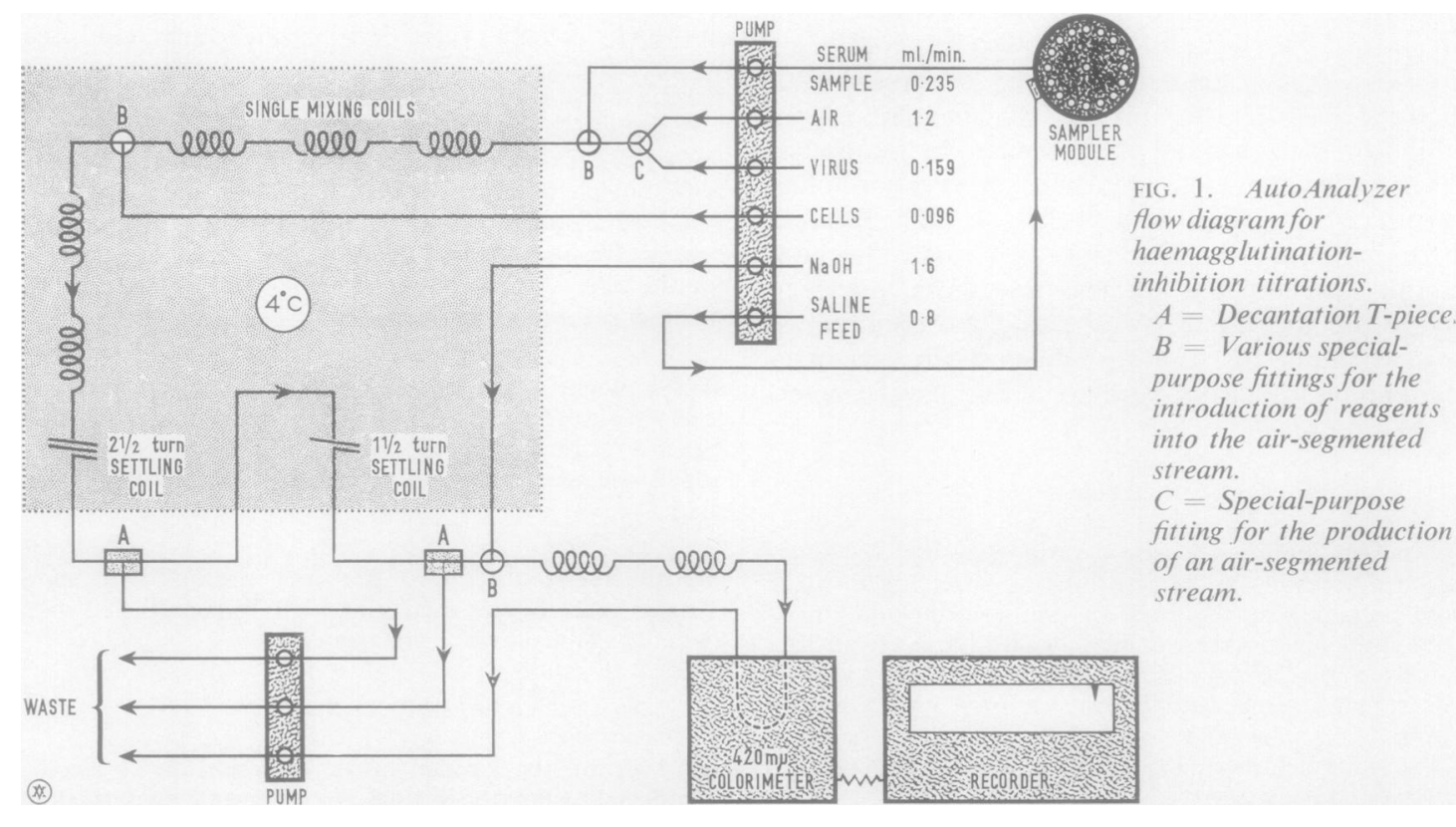




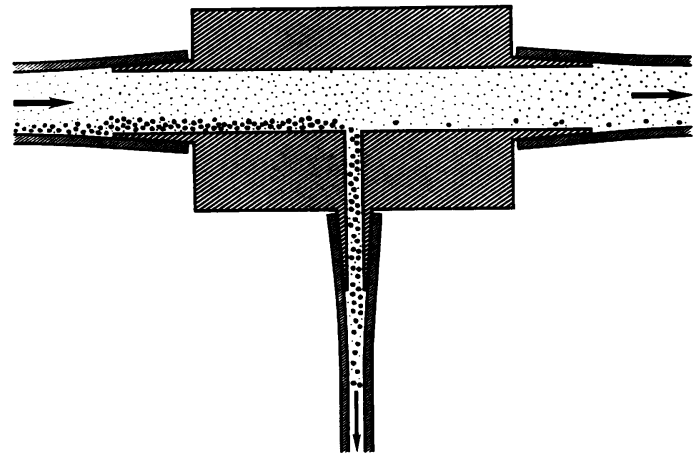

FIG. 2. Decantation T-piece for separating agglutinated from unagglutinated red cells.

serum and of non-specific haemagglutination inhibitors in normal horse and rabbit sera with the $A_{2} /$ Singapore/1/57 strain of influenza virus (Cohen and Belyavin, 1959). Each batch of virus used in the AutoAnalyzer haemagglutination-inhibition titrations was first adjusted by appropriate dilution to give a baseline reading of between 70 and $80 \%$ transmission. This concentration was equivalent to approximately 128 agglutinating doses per millilitre of virus, measured by the photoelectric densitometer method of Belyavin, Westwood, Please, and Smith (1951). In the AutoAnalyzer, these titrations behave as direct colour reactions, maximum inhibition corresponding to minimal agglutination and therefore to low percentage transmission (Fig. 4). Conversely, minimum inhibition corresponds to maximal agglutination and to high percentage transmission. A typical titration in which percentage transmission is plotted against inhibitor dilution is illustrated in Fig. 5A which shows a sigmoidal relationship approximately linear over the middle range. Ideally, all readings have to be related to the baseline and the correct relationship is obtained by plotting inhibitor dilution against values obtained by subtraction of each reading from the baseline value (Fig. 5B). To check the linear relationship between percentage transmission and inhibitor concentration in the apparently linear range, serial $1 \cdot 4$-fold dilutions of the three different types of inhibitor were titrated in replicate on a number of different occasions. Analyses of variance of the data obtained showed no significant deviation from linearity in this range (Table I).

Where the relationship is linear, a titre can be calculated for any arbitrarily decided value of the ordinate; in this series, titres corresponding to an ordinate value of 20 have been calculated from the regression equation. These titres compare favourably with those obtained by the photoelectric densitometer technique of Belyavin et al. (1951) although there is no direct relationship (Table II). Similar discrepancies between haemagglutination titres obtained by densitometer and AutoAnalyzer methods have been noted by Morris et al. (1965). Nevertheless, the high efficiency of the automatic technique can be judged from the fact that the sample volume is only $0.176 \mathrm{ml}$. compared with $0.5 \mathrm{ml}$. which is used in the densitometer technique.

The comparison of titres of different types of inhibitor is only meaningful if the slopes from which

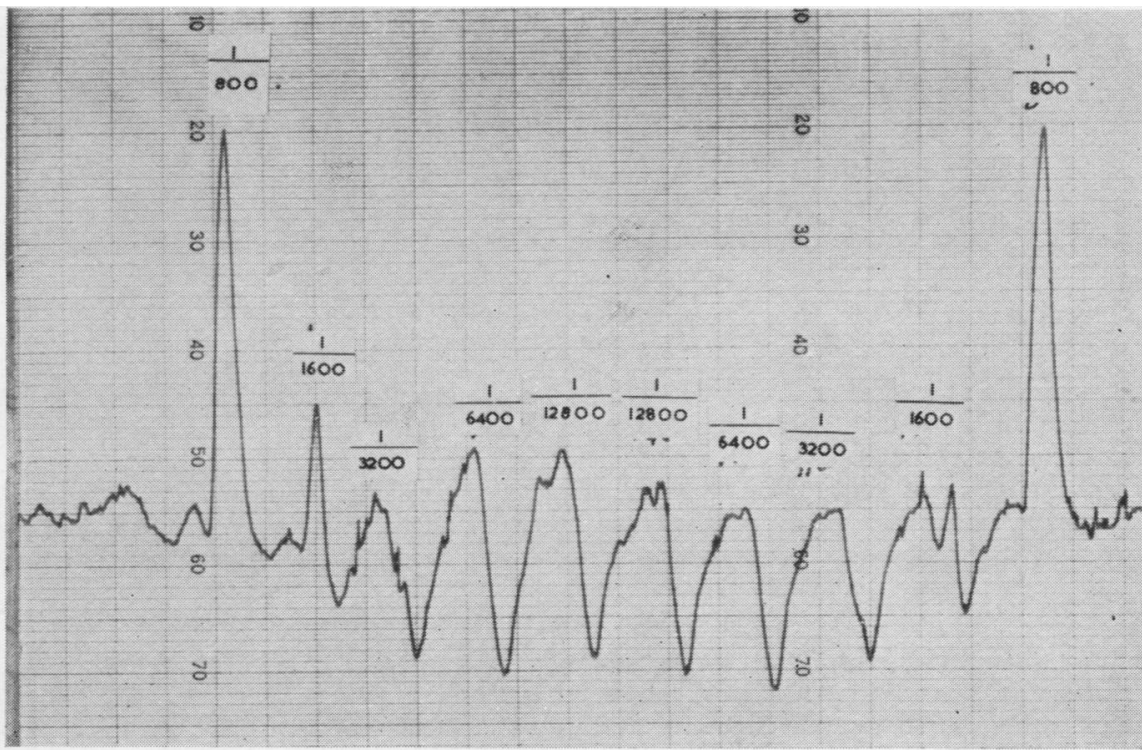

FIG. 3. AutoAnalyzer haemagglutinationinhibition titration performed at room temperature. 


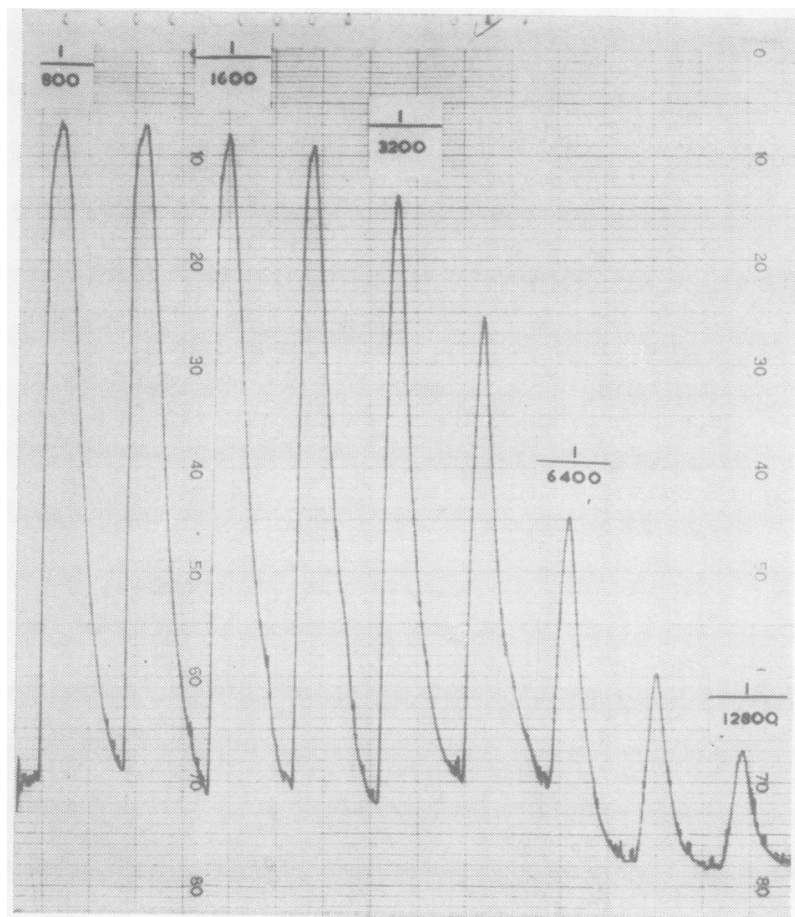

FIG. 4. AutoAnalyzer haemagglutinationinhibition titration performed at 0-4 C.

FIG. 5. AutoAnalyzer haemagglutinationinhibition titration curves:

$A=$ Inhibitor dilution plotted against percentage $\vec{O}$ transmission.

B -- Inhibitor dilution plotted against values obtained by subtracting each reading from the baseline value.

FIG. 4.

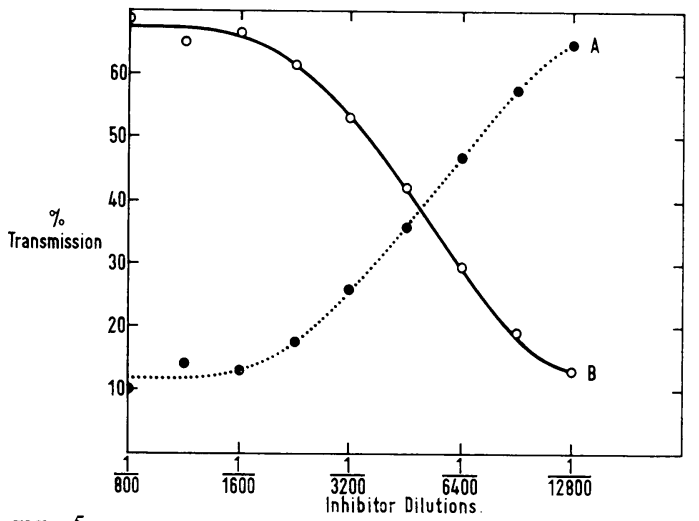

FIG. 5.

they are calculated are parallel and their regression coefficients the same. Of course, the calculated regression lines from titrations of different types of inhibitor would not be expected to occupy the same position, this being a function of their original concentration. The slopes calculated from replicate titrations of normal horse serum, normal rabbit serum, and homologous rabbit antiserum against the $\mathrm{A}_{2} /$ Singapore/ $/ 1 / 57$ virus, performed on the same day with the same reagents, were compared by analyses
TABLE I

ANALYSES OF VARIANCE FOR CHECKING LINEARITY (ABRIDGED RESULTS)

Inhibitor

Experiment No. of

No. Replicate's

in Each

Experiment

Normal horse serum

Normal horse serum

Normal horse serum

Homologous antiserum

Homologous antiserum

Normal rabbit serum

Normal rabbit serum

$\begin{array}{ll}1-14 & 3-10 \\ 15 & 4 \\ 16 & 8 \\ 17-23 & 3-7 \\ 24-27 & 2-5 \\ 28 & 5 \\ 29-31 & 2-4\end{array}$

$0 \cdot 2-0 \cdot 2$

$3-10$

3-7

$2-4$

of variance, and it is evident from Table III that, with one exception, there is no significant difference $\bar{N}$ between them. Comparison of the AutoAnalyzer o titres of different inhibitors, at least against the same $\mathbb{\sim}$ virus, is thus perfectly valid.

ERROR OF THE TEST The variability of titres obtained in replicate titrations performed on the same day is $\frac{D}{D}$ shown in Table IV, which summarizes the results of $\stackrel{+}{+}$ 15 different experiments. The coefficients of varia- $T$ tion vary from 4.6 to $19.9 \%$, and the mean coefficient of variation is $10.5 \%$, which represents a degree of $\stackrel{\square}{\square}$ experimental error approximately the same as that $\mathbb{\mathbb { D }}$ of the densitometer technique. 
TABLE II

COMPARISON OF AUTOANALYZER AND DENSITOMETER HAEMAGGLUTINATION-INHIBITION TITRES

\begin{tabular}{|c|c|c|c|}
\hline $\begin{array}{l}\text { Experiment } \\
\text { No. }\end{array}$ & Inhibitor & $\begin{array}{l}\text { Auto- } \\
\text { Analyzer } \\
\text { Titre }\end{array}$ & $\begin{array}{l}\text { Densitometer } \\
\text { Titre }\end{array}$ \\
\hline 1 & Normal horse serum & 17,053 & 8,090 \\
\hline 2 & Normal horse serum & 5,052 & 14,720 \\
\hline 3 & Normal horse serum & 11,107 & 11,430 \\
\hline 4 & Normal horse serum & 12,078 & 8,560 \\
\hline 5 & Normal horse serum & 17,016 & 8,704 \\
\hline 6 & Normal horse serum & 16,865 & 2,912 \\
\hline \multirow[t]{2}{*}{7} & Normal horse serum & 30,595 & 5,824 \\
\hline & Homologous antiserum & 19,460 & 934 \\
\hline \multirow[t]{2}{*}{8} & Normal horse serum & 11,317 & 1,948 \\
\hline & Homologous antiserum & 7,123 & $<800$ \\
\hline \multirow[t]{2}{*}{9} & Normal horse serum & 6,806 & 16,960 \\
\hline & Homologous antiserum & 7,280 & 1,576 \\
\hline \multirow[t]{3}{*}{10} & Normal horse serum & 6,287 & 3,760 \\
\hline & Homologous antiserum & 7,513 & 1,812 \\
\hline & Normal rabbit serum & 9,085 & 780 \\
\hline \multirow{3}{*}{11} & Normal horse serum & 14,010 & 10,506 \\
\hline & Homologous antiserum & 8,042 & 1,704 \\
\hline & Normal rabbit serum & 10,500 & 400 \\
\hline
\end{tabular}

DAY-TO-DAY VARIATION Using the densitometer technique, haemagglutination-inhibition titres obtained from day to day, even with the same reagents, are not necessarily reproducible. The reproducibility of titres obtained from day to day with the Auto-

TABLE III

COMPARISON OF SLOPES FROM TITRATIONS OF DIFFERENT INHIBITORS WITH A SINGLE STRAIN ${ }^{1}$

\begin{tabular}{|c|c|c|c|}
\hline $\begin{array}{l}\text { Experi- } \\
\text { ment } \\
\text { No. }\end{array}$ & $\begin{array}{l}\text { Inhibitors } \\
\text { Compared }\end{array}$ & $\begin{array}{l}\text { No. of } \\
\text { Replicates }\end{array}$ & $P$ \\
\hline 1 & $\begin{array}{l}\text { Norm?l horse, homologous } \\
\text { antiserum, normal rabbit }\end{array}$ & 2 & $>0.2$ \\
\hline 2 & $\begin{array}{l}\text { Normal horse, homologous } \\
\text { antiserum, normal rabbit }\end{array}$ & 4 & $0 \cdot 2-0 \cdot 1$ \\
\hline 3 & $\begin{array}{l}\text { Normal horse, homologous } \\
\text { antiserum, normal rabbit }\end{array}$ & 2 & $0 \cdot 2-0 \cdot 1$ \\
\hline 4 & $\begin{array}{l}\text { Normal horse and homo- } \\
\text { logous antiserum }\end{array}$ & 4 & $0.05-0.01$ \\
\hline 5 & $\begin{array}{l}\text { Normal horse and homo- } \\
\text { logous antiserum }\end{array}$ & 4 & $0.05-0.01$ \\
\hline 6 & $\begin{array}{l}\text { Normal horse and homo- } \\
\text { logous antiserum }\end{array}$ & 3 & $>0.2$ \\
\hline 7 & $\begin{array}{l}\text { Normal horse and homo- } \\
\text { logous antiserum }\end{array}$ & 7 & $<0001$ \\
\hline 8 & $\begin{array}{l}\text { Normal horse and homo- } \\
\text { logous antiserum }\end{array}$ & 2 & $>0.2$ \\
\hline 9 & $\begin{array}{l}\text { Normal horse and rabbit } \\
\text { sera }\end{array}$ & 5 & 0.1 \\
\hline
\end{tabular}

${ }^{1}$ Abridged results of analyses of variance.

Analyzer was therefore investigated. Titres obtained on successive days using the same reagents were compared by analyses of variance and the results are summarized in Table $\mathbf{V}$. It is evident that titres of normal horse serum obtained on different days are, with one exception, significantly different. The titres of normal and immune rabbit sera, so far as they go, indicate a greater degree of reproducibility although
TABLE IV

COEFFICIENTS OF VARIATION FOR AUTOANALYZER HAEMAGGLUTINATION-INHIBITION TEST

\begin{tabular}{|c|c|c|c|c|}
\hline $\begin{array}{l}\text { Experiment } \\
\text { No. }\end{array}$ & $\begin{array}{l}\text { No. of } \\
\text { Replicates }\end{array}$ & $\begin{array}{l}\text { Mean } \\
\text { Titre }\end{array}$ & $\begin{array}{l}\text { Standard } \\
\text { Deviation }\end{array}$ & $\begin{array}{l}\text { Coefficient of } \\
\text { Variation }(\%)\end{array}$ \\
\hline 1 & 9 & 17,053 & 2,392 & $14 \cdot 0$ \\
\hline 2 & 5 & 20,672 & 2,433 & $11 \cdot 7$ \\
\hline 3 & 20 & 5,052 & 396 & $7 \cdot 8$ \\
\hline 4 & 17 & 3,915 & 298 & $7 \cdot 6$ \\
\hline 5 & 12 & 5,020 & 300 & $6 \cdot 0$ \\
\hline 6 & 6 & 11,107 & 513 & $4 \cdot 6$ \\
\hline 7 & 4 & 9,757 & 1,205 & $12 \cdot 5$ \\
\hline 8 & 7 & 8,389 & 634 & $7 \cdot 5$ \\
\hline 9 & 4 & 10,023 & 580 & $5 \cdot 8$ \\
\hline 10 & 4 & 6,806 & 1,358 & 19.9 \\
\hline 11 & 8 & 11,507 & 1,378 & $12 \cdot 0$ \\
\hline 12 & 5 & 9,123 & 1,244 & 13.6 \\
\hline 13 & 10 & 12,078 & 1,266 & $10 \cdot 2$ \\
\hline 14 & 5 & 17,016 & 1,798 & 10.6 \\
\hline 15 & 4 & 16,865 & 2,295 & $13 \cdot 6$ \\
\hline
\end{tabular}

more experiments are required to confirm this. Nevertheless, the results obtained, so far, indicate that the haemagglutination inhibition titres obtained from day to day with the AutoAnalyzer are no more reproducible than those obtained with the photoelectric densitometer.

In order to establish to what extent the daily variation of titre was due to a change in slope of the calculated regression lines from day to day the slopes obtained from titrations of the same reagents on different days were compared by analyses of variance. The results summarized in Table VI show that, with one exception, there was no significant difference. The slopes remained the same even when different cells or different batches of virus were used $(\mathrm{P}==\mathbf{0 \cdot 2})$. It may therefore be assumed that the titre variation from day to day was not related to

\section{TABLE V}

HAEMAGGLUTINATION-INHIBITION TITRES OBTAINED FROM TITRATIONS OF THE SAME REAGENTS ON DIFFERENT DAYS COMPARED BY ANALYSES OF VARIANCE (ABRIDGED RESULTS)

\begin{tabular}{lllll}
$\begin{array}{l}\text { Experi- } \\
\text { ment } \\
\text { No. }\end{array}$ & Inhibitor & $\begin{array}{l}\text { No. of Con- } \\
\text { secutive Days } \\
\text { on which Ex- } \\
\text { periments Were } \\
\text { Performed }\end{array}$ & $\begin{array}{l}\text { No. of } \\
\text { Replicates } \\
\text { on Each Day }\end{array}$ & $P$ \\
\hline 1 & $\begin{array}{c}\text { Normal horse } \\
\text { serum }\end{array}$ & 3 & $5-8$ & 0.01 \\
2 & $\begin{array}{c}\text { Normal horse } \\
\text { serum }\end{array}$ & 3 & $4-8$ & $<0.001$ \\
3 & $\begin{array}{c}\text { Normal horse } \\
\text { serum }\end{array}$ & 2 & $4-5$ & 0.2 \\
4 & $\begin{array}{c}\text { Normal horse } \\
\text { serum }\end{array}$ & 3 & $2-4$ & $<0.001$ \\
5 & $\begin{array}{c}\text { Homologous } \\
\text { antiserum }\end{array}$ & 3 & $2-4$ & $>0.2$ \\
6 & $\begin{array}{c}\text { Homologous } \\
\text { antiserum }\end{array}$ & 2 & $4-5$ & $>0.2$ \\
7 & $\begin{array}{c}\text { Normal rabbit } \\
\text { serum }\end{array}$ & 3 & $2-4$ & $>0.2$
\end{tabular}


any change in slope of the calculated regression lines. Possibly, the sensitivity of erythrocytes to virus agglutination alters on storage.

\section{TABLE VI}

COMPARISON OF SLOPES FROM TITRATIONS OF THE SAME REAGENTS ON DIFFERENT DAYS ${ }^{1}$

\begin{tabular}{|c|c|c|c|}
\hline $\begin{array}{l}\text { Experi- } \\
\text { ment } \\
\text { No. }\end{array}$ & Inhibitor & $\begin{array}{l}\text { No. of Con- } \\
\text { secutive Days } \\
\text { on which Ex- } \\
\text { periments Were } \\
\text { Performed }\end{array}$ & $\begin{array}{l}\text { No. of } \\
\text { Replicates } \\
\text { on Each } \\
\text { Day }\end{array}$ \\
\hline
\end{tabular}

\begin{tabular}{lllll}
\hline 1 & $\begin{array}{c}\text { Normal horse } \\
\text { serum }\end{array}$ & 2 & 3 & $0 \cdot 2-0 \cdot 1$ \\
2 & $\begin{array}{c}\text { Normal horse } \\
\text { serum }\end{array}$ & 3 & 4 & $0 \cdot 1-0 \cdot 05$ \\
3 & $\begin{array}{c}\text { Normal horse } \\
\text { serum }\end{array}$ & 3 & 4 & $0 \cdot 2$ \\
4 & $\begin{array}{c}\text { Normal horse } \\
\text { serum }\end{array}$ & 3 & 2 & $>0 \cdot 2$ \\
5 & $\begin{array}{c}\text { Homologous } \\
\text { antiserum }\end{array}$ & 2 & 3 & $0 \cdot 01-0 \cdot 001$ \\
6 & $\begin{array}{c}\text { Homologous } \\
\text { antiserum }\end{array}$ & 2 & 2 & $0 \cdot 2-0 \cdot 1$ \\
7 & $\begin{array}{c}\text { Homologous } \\
\text { antiserum }\end{array}$ & 3 & 2 & $0 \cdot 2-0 \cdot 1$ \\
8 & $\begin{array}{c}\text { Normal rabbit } \\
\text { serum }\end{array}$ & 3 & 2 & $0 \cdot 2-0 \cdot 1$
\end{tabular}

Abridged results of analyses of variance.

\section{DISCUSSION}

The encouraging results obtained with the AutoAnalyzer leave no doubt as to the feasibility of performing haemagglutination-inhibition titrations by this method although, so far, it has not proved superior to the densitometer technique in either accuracy or reproducibility. In its present form, the main limitation of the method is the slow rate of sampling, 20 per hour, which has to be maintained to prevent contamination between samples. At the rate of 20 readings per hour titration with the AutoAnalyzer is no faster than with the photoelectric densitometer; it is, in fact, somewhat slower. It is certainly slower than the plastic plate method (World Health Organization, 1959) although, of course, much more accurate. This, together with the occasional irregularity in the pattern of air segmentation which occurs from time to time, prevents the adoption of the AutoAnalyzer method for routine purposes at the present time. Nevertheless, there is little doubt that further development will make the instrument of greater practical usefulness.

Increase in the rate of assay is essential if the advantage of the automatic compared with manual methods is to be enhanced. Calculation of titres of unknown samples from a minimal number of readings, or even a single reading, would effectively increase the rate of assay. This is easily possible now that it has been established, in this investigation, that different inhibitors titrated against a single strain of virus have similar slopes over their linear ranges $\overrightarrow{\vec{F}}$ Titres are therefore calculable from a single reading by interpolation from a standard slope, obtained by titration of standard reagents on the day of the test The application of this approach and the evaluatior of the results obtained are now being investigated.

The use of multiple AutoAnalyzer channels, allowing the titration of each sample against $\vec{b}$ number of different viruses simultaneously, is $\dot{a}$ development which would not only increase theू effective rate of assay but would greatly facilitate such investigations as large-scale antigenic analyses? To permit multiple manifolds of this type to operateo at maximum efficiency rapid automatic methods of dealing with the large amount of data produced areg essential. This can be achieved by the automatio conversion of recorder signals to digital form suit $=$ able for feeding into a digital computer, the use of which has already proved invaluable in this investiga tion. Computer calculation of data presented by the AutoAnalyzer has the advantage not only of speed ing up the calculation of results but also of pro= viding an amount of statistical information im $\vec{\emptyset}$ possible to obtain by any other method.

Further developments incorporating the modificae tions suggested will go some way to overcome the present limitations of the method. If so, the Auto Analyzer will undoubtedly become a useful and effective tool for facilitating the work of thoseD laboratories engaged in large-scale work with influenza or other virus haemagglutination systems응

Thanks are due to Professor G. Belyavin for his advice and encouragement during the course of this investiga tion. It is a pleasure to thank Mr. H. L. Spindler an Mr. R. Smith for their technical assistance, Mr. PO McLeod of Elliott Medical Automation Ltd. for his help with the computer programmes, and Mr. V. K. Asto for his drawing of the diagrams. The help of Mr. R. Jones of the Technicon Instrument Co. Ltd. is also acknowe ledged. The AutoAnalyzer was purchased with the aid of a grant from the Medical Research Council.

\section{REFERENCES}

Belyavin, G., Westwood, J. C. N., Please, N. W., and Smith, wO (1951). J. gen. Microbiol., 5, 546.

Cohen, A., and Belyavin, G. (1959). Virology, 7, 59.

Grunmeier, P. W., Gray, A., and Ferrari, A. (1965). Ann. N.Y. AcadK Sci., 130, 809.

Hirst, G. K., and Pickels, E. G. (1942). J. Immunol., 45, 273.

Morris, J. A., Jenkins, J. C., and Horswood, R. L. (1965). Ann. N. Y® Acad. Sci., 130, 801.

Skeggs, L. T., Jr. (1957). Amer. J. clin. Path., 28, 311.

Sturgeon, P., Cedergren, B., and McQuiston, D. (1963). Vox Sang (Basel), 8, 438.

Taverne, J., Marshall, J. H., and Fulton, F. (1958). J. gen. Microbiol. $19,451$.

World Health Organization (1959). Wld Hlth Org. techn. Rep. Ser., 170. 